\title{
Land-use changes and sustainable development in mountain areas: a case study in the Spanish Pyrenees
}

José M. Garcia-Ruiz', Teodoro Lasanta', Purificación Ruiz-Flano², Luis Ortigosa ${ }^{3}$, Sue White', Constanza González ${ }^{1}$ and Carlos Martí ${ }^{1}$

${ }^{I}$ Instituto Pirenaico de Ecologia, CSIC, Campus de Aula Dei, Apartado 202, 50080-Zaragoza, Spain;

${ }^{2}$ Department of Geography, University of Las Palmas. de Gran Canaria, Canary Islands, Spain; ${ }^{3}$ Department of Geography, University of La Rioja, Logrono, Spain

Keywords: land-use change, sustainability, farmland abandonment, reforestation, soil erosion, runoff, mountain areas

\begin{abstract}
Land-use changes affecting Mediterranean mountains represent the intensification of use in valley bottoms, accompanied by land-use conflicts, and a generalized abandonment of the hillslopes, which in the past were perfectly integrated in the system of land management. Farmland abandonment, reforestation, diminution of the livestock pressure and substitution of cereal crops by meadows are the most outstanding features of the recent land-use changes. The question is whether the new spatial organisation is in accordance with a longterm policy of sustainable development in mountain areas. The results obtained confirm that farmland abandonment on steep slopes - and the resulting colonization of old fields by a dense shrub cover - and afforestation contribute to control both soil erosion and surface runoff. As a result some of the most important rivers and alluvial fans have recently stabilized their sedimentary structures.
\end{abstract}

\section{Introduction}

Large changes affecting land use in the European mountains arrived quite recently. In Spain such changes are related, on one hand, to the transformation of the demographic structure of the human population (ageing of the population, strong decrease in the number of inhabitants) and, on the other hand, to the role that, at different scales, the market plays on the patterns of land management. At present in mountain areas, and particularly in the Pyrenees, a strong contrast, unknown up to 30 years ago, arises between the valley bottoms which are intensively used, with big capital investments and considerable energy inputs, and the rest of the territory, which is managed by means of very extensive systems or simply abandoned (GarcíaRuiz and Lasanta 1993).

Farmland abandonment, reforestation, change in type of crops grown, abandonment of methods for both soil conservation and runoff control, changes in the sources of food for cattle and changes in the grazing system are some of the disturbances clearly observable throughout the Pyrenees and in other Spanish mountain systems (Lasanta 1990). All of these changes affect the dynamics of natural systems and especially the hydrologic and geomorphologic functioning of hillslopes and fluvial channels.

It is obvious that this phenomenon is not new: some centuries ago land management of steep slopes resulted in an important loss of biodiversity and many hillslopes were affected by soil erosion due to overgrazing, frequent wildfires and rain-fed farming. But this damage was probably inevitable in order to ensure the survival of the human population with the available level of technology. Nowadays the problem is quite different: demographic pressure is lower than ever before, technical and financial assets facilitate conservation mea- 


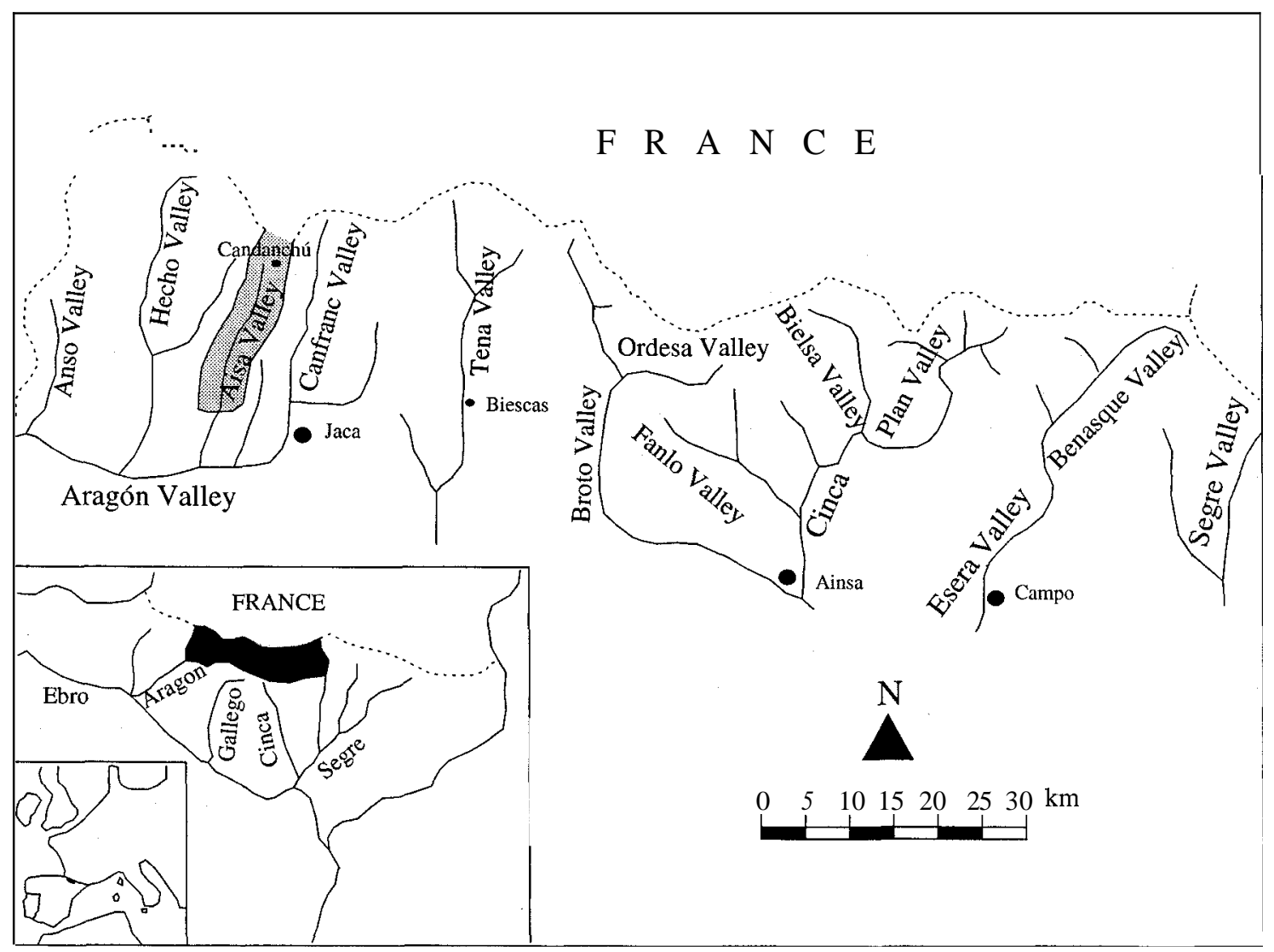

Fig. 1. The study area.

sures, and increasing information is available on the ecological and geomorphic consequences of land-use changes.

In this paper the main features of very recent land-use changes are shown, and the consequences for soil and water conservation are presented, in comparison with some features of the traditional land management system. The final purpose is to define whether these land-use changes are in accordance with a long-term policy of sustainable development in mountain areas.

\section{The study area}

In the Central Spanish Pyrenees the northernmost band of peaks is the paleozoic or axial Pyrenees which has great tectonic and lithological complexity; it includes limestones, sandstones, conglomerates, schists and slates, with some granite. Intense glaciation and mass movements have resulted in high contrasts of relief in which areas of smooth gradients alternate with rugged cliffs and sharp crests, sometimes over 3,200 m a.s.l. (Garcia-Ruiz et al. 1990).Immediately to the south are the Inner Sierras, a large anticline composed of Cretaceous and Eocene limestones with some interbedded sandstones. The relief is dominated by high, almost vertical cliffs, intense karst activity, abundant glacial cirques and very active avalanche paths. Further south, the flysch bedrock is intensively folded, but lithological homogeneity results in a more uniform relief, dominated by smooth divides, which decrease progressively in height towards the south, and by slopes with gradients between 20 and 40 per cent (Garcia-Ruiz and Puigdefábregas 1982). This paper focuses on the sectors dissected by the north-south fluvial network forming the high Pyrenean valleys. The experimental part of the research has been carried out in the Aísa Valley 
(Fig. 1), located to the south of the Inner Sierras in an area of flysch. Aisa was selected because it is very representative of central Spanish Pyrenean valleys, with much abandoned land on the steeper and sunny slopes and agriculture restricted to the valley floor.

The distribution of temperature and precipitation shows a double gradient. From west to east the wetter Atlantic influence decreases, and the drier Mediterranean climate, with more intense rains in autumn, starts to dominate. Likewise, precipitation diminishes from north to south with increasing temperature. In Jaca, at $820 \mathrm{~m}$, rainfall averages $892 \mathrm{~mm}$ per year, whilst in Candanchú, at $1,600 \mathrm{~m}$, it reaches $1,992 \mathrm{~mm}$. In the highest areas an annual precipitation of more than $2,500 \mathrm{~mm}$ has been recorded (Rijckborst 1967). The $0^{\circ} \mathrm{C}$ isotherm during the cold season is located between 1600 and $1700 \mathrm{~mm}$ (Garcia-Ruiz et al. 1986). In Aisa, at $1,100 \mathrm{~m}$, the annual precipitation is $1,100 \mathrm{~mm}$ and the mean annual temperature is $10^{\circ} \mathrm{C}$.

Pinus sylvestris woods dominate on the shady slopes, whilst on the sunny ones small patches of Quercus gr. faginea, the remains of massive forests, alternate with submediterranean shrubs (Buxus sempewirens, Genista scorpius, Echinospartum horridum, Rosa gr. canina and Juniperus communis).

\section{Methods}

Since 1987 the research group for Erosion and Land-use Changes of the Pyrenean Institute of Ecology has studied soil erosion and runoff in relation to human activities in mountain areas, at hillslope and basin scales. This includes studies on the effects of farmland abandonment and of afforestation, and in the last few years it has also included wildfire effects and traditional agriculture.

To obtain information on runoff and sediment yield, experimental plots with different plant-cover densities and land-uses were monitored in the Aisa Valley. Two types of experimental plots were used:

1. Between 1990 and 1992, 19 closed plots were installed in different, degraded environments on slopes cultivated several years ago and now abandoned. All the plots are small in size (around 3.5 $\mathrm{m}^{2}$ ). A Gerlach trap (López-Bermúdez et al. 1993) was located at the lower end of the plots, connected to a 62 litre container to collect the water and sediment generated by each rainfall event. After each event, the quantity of water was measured in the field and a sample was taken to obtain the sediment concentration in the laboratory.

The location of the plots took into account the most representative geomorphic environments, previously selected by means of geomorphic transects (Ruiz-Flaño et al. 1991 and 1992). There were 3 plots with a $100 \%$ shrub cover, 3 plots with $85 \%$ shrub cover, 3 plots with $65 \%$ shrub cover, 4 plots with $40 \%$ shrub cover, 3 plots with $15 \%$ shrub cover (the soil being covered by a stone pavement), and 3 plots with $85 \%$ meadow cover. After two years these plots were abandoned and replaced by a more complex installation, the 'Aisa Valley Experimental Station'.

2. The Experimental Station is located on a field that was abandoned 35 years ago, and that is now completely covered by dense shrubs of Genista scorpius and Rosa gr. canina. Initially six closed, $10 \times 3 \mathrm{~m}$ plots were installed, including, at the lower end, a Gerlach trap and a simple system of tipping buckets connected to data loggers in order to record the runoff of each plot continuously. A pluviometer is also connected to a data logger. Part of the runoff is diverted to 31 litre containers, which are emptied after each rainfall event, in order to analyze the sediment concentration (both suspended sediment and nutrients).

The first six plots, installed in 1991, reproduce different land-uses: shifting agriculture (barley fertilized with ashes), fallow land, cereals (adding chemical fertilizer), burnt plot, dense shrub cover (with the unaltered, original vegetation), and meadows. In 1993 the plot in fallow passed to cereal, whilst the cereal plot was left as stubble, initiating a process of abandonment. Moreover, in 1993 two new plots were incorporated: one as fallow land (later cultivated with barley) and the other a recently burnt plot. Only some of the most significant results will be discussed in this paper (see also Garcia-Ruiz et al. 1995).

It is important to note that 'measurements on experimental plots are acceptable only for comparative purposes, that is, to have orders of magnitude of overland flow and erosion in different environments and land-uses. They cannot be accepted as 
Table 1. Food sources for livestock in three valleys for the traditional and present-day land-use system (\%).

\begin{tabular}{|c|c|c|c|c|c|c|}
\hline \multirow[b]{2}{*}{ Valleys } & \multicolumn{3}{|c|}{ Traditional svstem } & \multicolumn{3}{|c|}{ Present system } \\
\hline & Aísa & Gállego & Hecho & Aisa & Gállego & Hecho \\
\hline Summer pastures & 22 & 22 & 22 & 21 & 24 & 18 \\
\hline \multicolumn{7}{|l|}{ Low and middle hillslopes } \\
\hline a) Forests and bushes & 11 & 15 & 19 & 2 & 3 & 1 \\
\hline b) Abandoned fields & 2 & 1 & 3 & 5 & 1 & 2 \\
\hline \multicolumn{7}{|l|}{ Cultivated space } \\
\hline a) Fodder & 8 & 16 & 15 & 30 & 40 & 44 \\
\hline b) Grazing & 13 & 18 & 5 & 36 & 26 & 35 \\
\hline \multicolumn{7}{|l|}{ From outside the valley } \\
\hline a) Fodder imports & 0 & 0 & 0 & 0 & 6 & 0 \\
\hline b) Transhumant grazing & 44 & 30 & 36 & 0 & 0 & 0 \\
\hline
\end{tabular}

absolute coefficients or rates. Obviously, the characteristics of the plots, especially for the smaller ones, exhaustion of sediment, modifications of the soil caused by their installation, and the interruption of natural overland flow by plot boundaries, reduce the absolute validity of the data, but the results are good indicators of the differences between the environments.

\section{General framework of the traditional land- use patterns}

The traditional spatial organization was based on i) the importance of agricultural activities to ensure food for the human population, ii) the use of the whole territory by means of different types of livestock, especially sheep; iii) the recycling of nutrients and the use of external resources by means of transhumance (livestock migration) and temporary migrations; iv) the strong social cohesion in very large families.

The Pyrenees, as a mountain region, show great heterogeneity of production possibilities, with different uses in time and space according to the altitude and topographic diversity. The survival and prosperity of the mountain inhabitants has been based on their knowledge and management of this territory. The result is a very complex spatial organization, which takes into account the entire mountain region and south to the steppes of the Ebro Depression (Fig. 1).

Farming activities were required to produce food for the human population, and agriculture based on cereals (mainly wheat) reached its maximum extent at the end of the nineteenth century, the period of greatest population density. On average, almost 28 per cent of the land below $1,600 \mathrm{~m}$ was cultivated (Lasanta 1988 and 1989a). Cultivated fields occupied all the possible locations, even in very difficult topographic conditions, on steep slopes and on stony soils. Farmers were careful with the best fields (for example, using fertilizers and constructing drainage systems) located close to the settlements in valley bottoms or on stone walled, bench terraced slopes. In contrast, coinciding with the maximum pressure, a shifting agriculture, consisting of 2 or 3 years of cultivation and later abandonment for 25 or 30 years, allowed production of poor cereal crops without soil conservation techniques (Garcia-Ruiz 1976). In general, the cultivated area was divided into two sections: one sown with cereals and the other remaining fallow, alternating yearly. Livestock grazed on the fallow plots and also on the cereal fields after cropping.

The Ebro Delta is an excellent proof of the erosive consequences of agriculture in mountainous areas since Roman times (Dupré 1990). The growth of the Delta was especially rapid in the 16th and 19th centuries, coinciding with the expansion of both shifting agriculture and mountain pastures and with the moment of maximum population density. There is other evidence: the rivers draining the Pyrenean flysch - that is the areas most intensively used in the past - are characterized by high torrentiality, carrying out large volumes of bed load and aggrading the alluvial plain. Some of the main rivers - i.e., Cinca, Ara, Gállego and Aragón - also demonstrated a great geomorphic activity at the beginning of this century, with very unstable chan- 


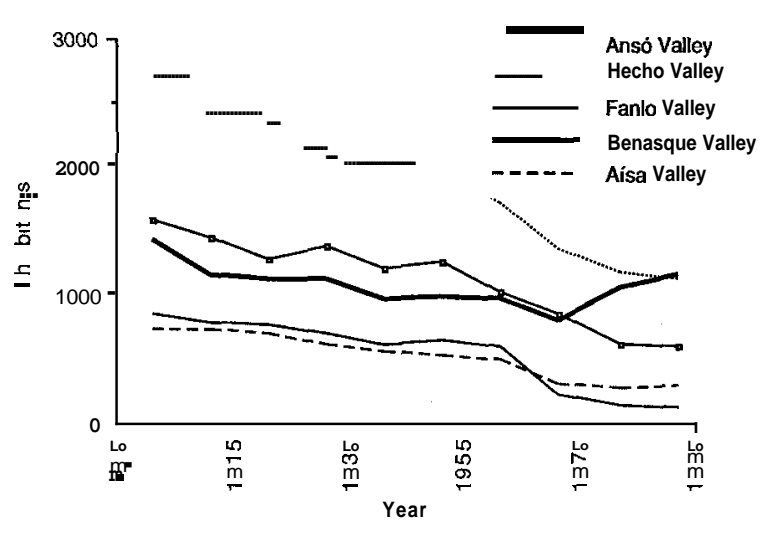

Fig. 2. The evolution of the human population in four Pyrenean valleys.

nels (Rubio and Hernandez 1990). Hillslopes and rivers confirm that during several centuries the Pyrenees were subject to intense management. The result was an increase of sediment yield, overland flow and peak flows. Most of the alluvial fans are closely related to human activities on steep slopes (Gómez-Villar 1995). Likewise, Gonzhlez et al. (1995) demonstrated using a GIS (Geographic Information System) and geomorphological mapping that most of the geomorphic processes under $1600 \mathrm{~m}$ a.s.l. are related to past forest wasting, overgrazing and cropping.

Livestock had abundant summer fodder sources. Between July and October the herds of cattle, sheep and horses grazed on the extensive summer pastures, which in some valleys comprised more than 30 per cent of the total surface. A large part of the summer pastures was artificially created from the 11th century onwards by means of fire (Montserrat 1992), which triggered intense erosive processes and different types of mass movements (Garcia-Ruizet al. 1990).

The winter fodder resources were very limited in Pyrenean valleys. This marked imbalance between summer and winter availability of fodder is the basis of the Pyrenean transhumance (Kruger 1939; Violant 1949; Puidefhbregas and Balcells 1966), displacing to the steppes of the Ebro Depression the task of maintaining the livestock during the cold season (Table 1). This system allowed not only an increase in the number of sheep but also the exclusive dedication of the agricultural space to food for human consumption.
The forests - located on the shady slopes under $1400 \mathrm{~m}$ a.s.l. and replaced by summer pastures above $1750 \mathrm{~m}$ - were also grazed, especially in spring and autumn. Close to the villages, small patches of oakwoods were used as wood reserves and as grazing areas for cattle. In many cases the borders of the bench terraces have oaks, ash trees and hedges in order to delimit the property, reduce the erosion risk and obtain forage for livestock in winter (Gómez and Fillat 1984).

\section{The main land-use changes}

Internal and external factors explain the great changes that have occurred in the mountains of developed countries, especially in Western Europe. In the Pyrenees rapid depopulation, due largely to changing social expectations rather than a decrease in crop production (Lasanta 1989a), occurred between 1950 and 1960 (Fig. 2). This led to the break down of the traditional social system and to the progressive marginalization of agriculture. Depopulation is responsible for a marked ageing of the population and a decrease in the number of members per family (Esteva 1971; Garcia-Ruiz 1976; Gorria 1987), which in turn caused the disappearance of transhumance and a crisis in sheep farming. In a parallel way tourism, forest policy and hydrological policy also contributed to the general spatial disorganization (see Garcia-Ruiz 1990; Garcia-Ruiz and Lasanta 1993). The most significant changes in the land use have been: i) the decline of sheep and the expansion of cattle farming; ii) the shrinkage of the cultivated area; iii) the decline in cereal production and increase in meadows; and iv) the reforestation of many abandoned hillslopes.

Due to socioeconomic reasons transhumance is almost impossible nowadays. Once transhumance had been abandoned, livestock became confined exclusively to the Pyrenean valleys. Livestock use the high summer pastures and remain close to the village for the rest of the year, grazing on abandoned fields, on sub-Mediterranean shrubs or, in early spring, in meadows. During the days of severest winter weather the livestock is stabled. This change in the livestock management has another consequence: the number of sheep has dimin- 


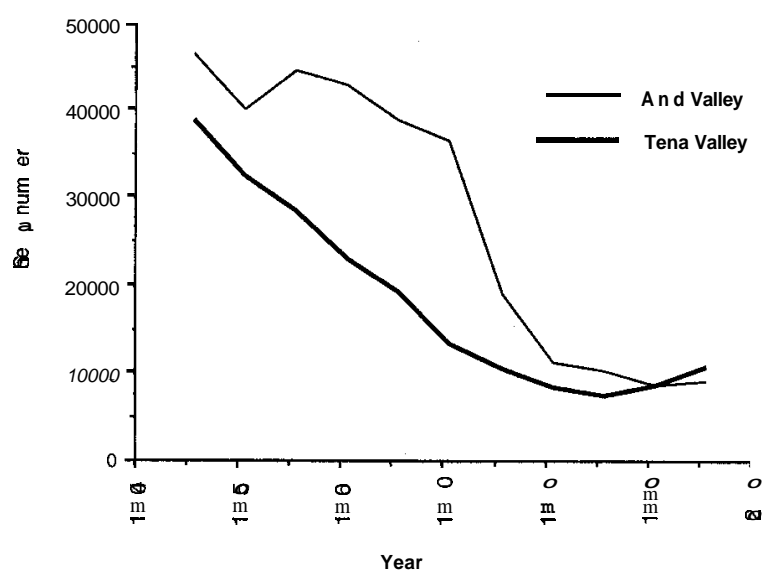

Fig. 3. Evolution of sheep numbers in two F'yrenean valleys.

ished, a process partially counterbalanced by an increase in the number of cattle. For example, the Ansó Valley had more than 45,000 sheep in 1900 (Villar and Garcia-Ruiz 1976), 34,900 in 1970, and 10,600 in 1990. The Gallego Valley had 22,760 sheep in 1950, and 5,373 in 1990 (Fig. 3). The reason for this decrease is not only the declining human population, but also the strong limitation of fodder production for winter supplies. In the traditional system winter food supplies did not present any problem since the shepherds found grazing on the steppes of the Ebro Depression, and the number of sheep belonging to each valley was closely related to the capacity of the summer pastures (GarcíaRuiz and Lasanta 1990). But once transhumance has disappeared, the fodder for winter consumption has to be produced within each valley and fewer livestock can be kept.

Farming is now limited to the proximity of villages, alluvial fans or low fluvial terraces suitable for irrigation and mechanization. Farming has been completely abandoned on steep, sunny, stony soils where farm machinery cannot be used (Lasanta 1988). The decline in the area under cultivation is not caused by the decrease in population. Rather, improved means of transport and the possibility of buying large quantities of fodder and cereal from other regions have made cultivation unprofitable. Abandoned fields have now become grazing lands, through plant succession tends to cover the fields with a dense, thorny shrub cover, which is impossible to graze 25 or 30 years after abandonment (Molinillo et al. 1994).

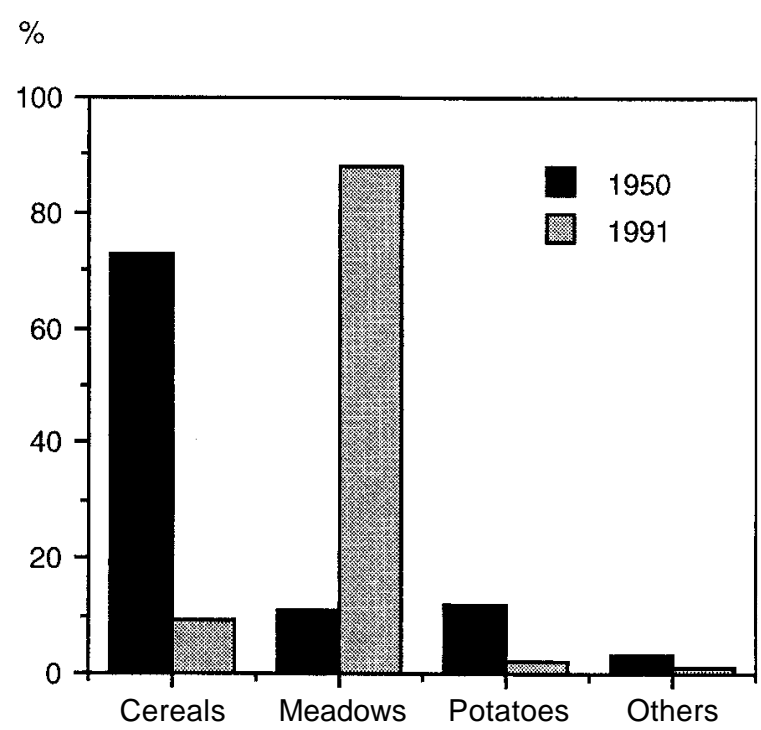

Fig. 4. Main crops in the Central Pyrenees in 1950 and 1991

In the valley bottoms cereal fields have been replaced by meadows. In the traditional system, cereals ensured human food supply, but as transport systems improved, mountain cereals were no longer competitive and fodder production became important in ensuring the survival of the Pyrenean livestock (Fig. 4). In fact, the number of sheep and cattle in the Pyrenean valleys is now highly correlated with the surface occupied by meadows (Lasanta 1989b).

On many of the abandoned hillslopes the State Administration has encouraged an extensive policy of reforestation in order to control the hydrologic and geomorphic processes of slope erosion over large areas of open land with little vegetative cover. The first plantations were made using a system of digging holes and required abundant manpower. In the 1950 s and 1960 s oxen were used to dig furrows parallel to the contour lines. In the late $1960 \mathrm{~s}$, caterpillar tractors and bulldozers were introduced to construct strips or terraces, consisting of a bench of several metres width, a ridge on the border where the material from the terrace was accumulated, and a drop to the next terrace where, generally, the original plant cover remained. Some studies show that, in terms of tree growth, the best results are obtained with the first two techniques (Ortigosa et al. 1990).

Finally, two external influences cause important 


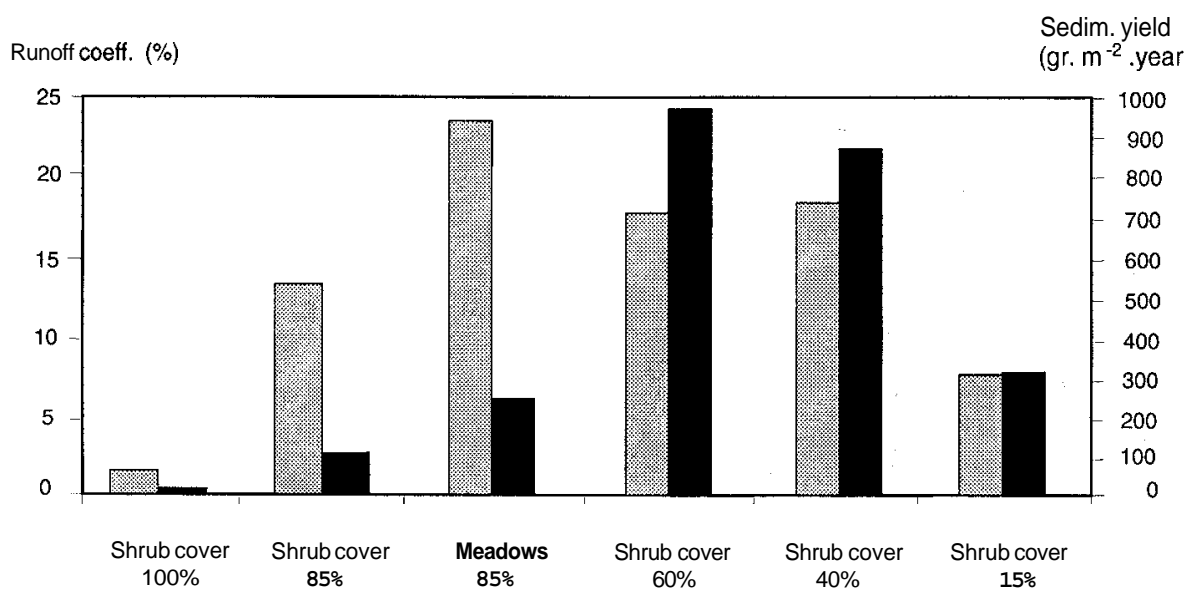

Runoffcoefficients

Sediment yield

Fig. 5. Runoff and sediment yield under different plant cover.

land-use conflicts: the construction of reservoirs and the expansion of tourism. During the twentieth-century the central government has encouraged the expansion of irrigation in areas of the Ebro Depression that were formerly cereal fields or open steppes. Large reservoirs have been constructed to regulate Pyrenean rivers. In the Gallego Valley, for example, the Lanuza and Búbal reservoirs, built in 1980 and 1971 respectively, cover a total surface of 384 ha. Of these, 196 ha were very productive meadows on the valley floor that produced enough fodder to feed 418 cattle in the stubble for six months and grazing for 723 during another two months. The increasing demand for water to supply newly irrigated areas and urban centres, has encouraged new projects that will inundate very productive valleys.

Tourism also causes land-use conflicts. Land in the most favoured locations has been taken over for the construction of resort centres and recreational activities (Balcells 1983; Garcia-Ruiz and Lasanta 1993). Moreover, the development of tourism in some villages relegates stock breeding activities to second priority. New generations are no longer interested in cattle raising and devote all their efforts to commerce, hotel management, and working in the winter resorts. Garcia-Ruiz and Lasanta (1993) demonstrated that the most developed tourist areas tend to be the least involved in live- stock breeding, a fact which emphasizes the incompatibility between the two interests.

In summary, the new land uses represent a strong spatial discoordination, since large areas are misused or completely abandoned, whilst others are intensively used to produce fodder to feed the livestock in winter. The latter occurs in the valley bottoms, precisely the places where reservoirs are built and where the tourism infrastructure is concentrated.

\section{Soil conservation and degradation in relation to land-use changes}

Once the main land-use changes are known, several questions arise from an environmental point of view. For example, what is the impact of the substitution of cereal cultivation by meadows? Is it possible to retrieve the fields nowadays colonized by a dense shrub cover without serious soil disturbance? Is farmland abandonment a good alternative to ploughing and cropping on steep slopes? What type of hydrologic and geomorphic changes does afforestation introduce? What are the effects of these changes at a basin scale (mainly in the fluvial channels)?

The results obtained from the small experimental plots show the importance of shrub cover in the 
$\mathrm{mg} / \mathrm{l}$

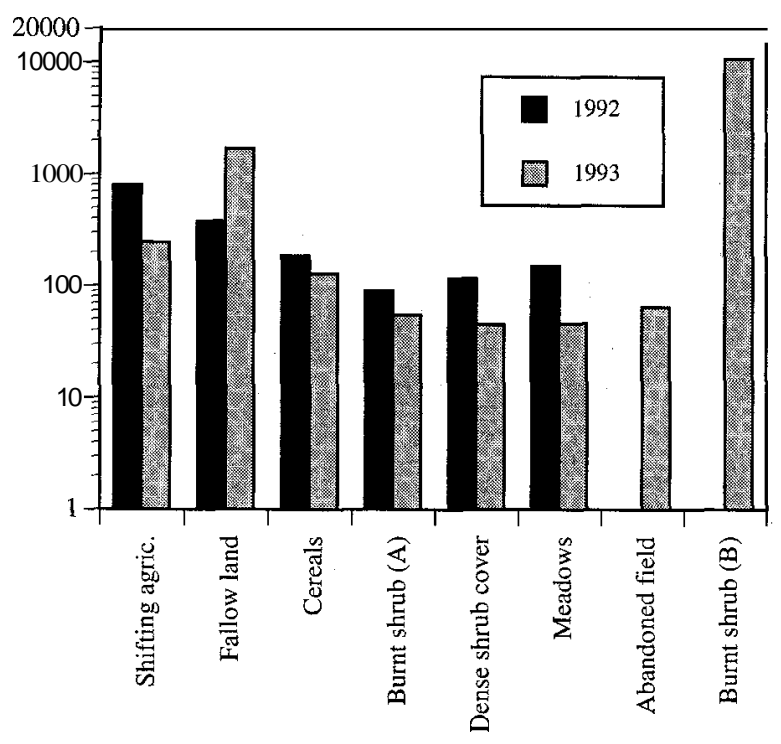

Fig. 6. Suspended sediment concentration for different landuses during the springs of 1992 and 1993.

hydromorphological functioning of hillslopes. Figure 5 gives information on runoff and sediment concentration from each plot. Plots with dense shrub cover give the lowest runoff coefficients, because of the effect of the vegetation, which both encourages infiltration and increases rainfall interception. In fact, almost all of the precipitation is utilized within the plot, with very little output of water in the form of surface runoff. But as the density of the plant cover decreases, the quantity of runoff increases by several orders of magnitude, suggesting that once the opening of the shrub cover begins, overland flow increases more than might be expected.

The greatest runoff is produced from plots where the shrub cover is 40-60 per cent. Surprisingly, plots with the least shrub cover (15 per cent) yield an intermediate quantity of runoff. This is probably due to the high quantity of stones on the surface (stoniness equal to 100 per cent), which encourages infiltration (Poesen et al. 1994).

A very interesting result is that meadows yield high quantities of surface water, very similar to those of the highest values from open shrubland, showing that a herbaceous cover acts like a semiimpervious layer, hindering immediate infiltration.

Plots with a dense shrub cover record the lowest sediment concentrations, followed by the meadows. The highest concentration recorded is from the plots with 60 per cent shrub cover. In plots with 15 per cent shrub cover the water contains almost as much sediment as the more active plots. From this one can conclude that stones encourage infiltration but that runoff can still mobilize sediments, probably from between and under the stones (Lekach and Schick 1982).

In the Aisa Valley Experimental Station, suspended sediment concentrations show large differences between land-use types (Fig. 6). Apart from the plot burnt in 1993, the highest suspended sediment outputs correspond to shifting agriculture and fallow land. In contrast, the plot burnt in 1991 and the plot with dense shrub cover had values slightly less than meadows. The stubble plot, which in 1992 was cultivated with barley, has similar losses to those of the latter plots; this result must be interpreted as a consequence of the quick plant recolonization due to the addition of chemical fertilizer to the cereals.

The behavior of the plot burnt in 1993 must be considered separately, above all in comparison with the plot burnt in 1991. The latter plot had low concentrations of suspended sediment because of the dense plant recovery in the months after the fire. This is why its hydrologic and geomorphic measurements are very similar to those of the plot with dense shrub cover. The hydrologic measurements of the plot burnt in 1993 were made immediately after the fire. Suspended sediment concentration from this plot was 10 times greater than for shifting agriculture and fallow land, and 100 times greater than for dense shrub cover, meadows or the plot burnt in 1991. This result shows how wildfire encourages intense soil erosion during the first months after the fire but, later, plant recolonization reduces soil erosion to values prevailing before the fire.

The effects of afforestation have also been studied. At a hillslope scale the main factors controlling soil erosion are the topography (convex, straight or concave hillslopes) and the position on the slope (upper, middle and lower). The technique used in the afforestation works is also important (GarciaRuiz and Ortigosa 1992); bench terraces yield much more sediment than hollows and furrows. This is why the geomorphic results of afforestation 
are so varied. Nevertheless, at a basin scale some tentative differences can be found by comparing the river beds of afforested and non-afforested basins. In afforested basins the sediment carried out is of a smaller size and the presence of vegetation in the channel is greater than in non-afforested basins. Furthermore, there is a reduction of geomorphic processes in the nearby taluses (GarcíaRuiz and Ortigosa 1988; Ortigosa and Garcia-Ruiz 1995). These results indicate that runoff and sediment yield are better controlled than before afforestation.

\section{Discussion and conclusions}

Soil erosion was probably the most important environmental problem during the so-called traditional land-use system. Cereal cultivation on steep slopes was responsible for the deterioration of production capacity on many sunny slopes of the Pyrenees, where stoniness now reaches almost 100 percent on the soil surface and where an open shrub cover prevails. The results obtained from the Aisa Valley Experimental Station demonstrate that shifting agriculture yielded great quantities of sediments, thus explaining the growth of the Ebro Delta, the agradation of some alluvial plains and the construction of many alluvial fans, all of which are clearly related to human activities. Fallow land, in alternate years with cereal cropping, also caused much soil erosion. Moreover, some shrub areas were frequently burnt, causing a sudden increase in soil erosion for some months, impoverishing the nutrient content of soils and, after several repeated fires, making plant colonization difficult.

Abandonment of farmland on steep slopes completely changed the scenario. After abandonment a process of plant succession occurs at varying rates dependent on the condition of the land at abandonment and finally results in a dense shrub cover after 25 or 30 years. In this case both soil erosion and surface runoff are very well controlled, ensuring soil conservation and even improving some of the soil characteristics (organic matter content, porosity, exchange capacity, nitrogen content) (RuizFlaño 1993). As a result some of the most important rivers (i.e., Cinca and Ara) have recently stabilized their sedimentary structures (Rubio 1995;
Rubio and Hernández 1990). In the same way, alluvial fans have reduced their activity and the most dynamic sectors now occupy very limited areas (Gómez-Villar 1995; Martinez-Castroviejo et al. 1991). Afforestation also has positive effects on reduction of runoff and sediment yield, through its benefits can only be deduced at a basin scale.

The substitution of cereals by meadows in the cultivated area - now reduced to the valley bottoms and some glaciolacustrine perched flats - represents a clear decrease in sediment yield, though runoff maintains high values. That is, meadows yield much water but it is relatively sediment free. A possible replacement of dense shrub cover by meadows, in suitable places such as concave slopes and lower hillsides, will probably lead to an increase in overland flow and in the availability of water in the entire basin without serious soil erosion problems in the long term. Land-use trends during the 20th century have led to better strategies for soil conservation: both farmland abandonment - and the resulting colonization of old fields by a dense shrub cover - and the substitution of cereal crops by meadows contribute to control soil erosion and, to a greater or lesser extent, to reduce overland flow on the hillslopes and peak-flows in the fluvial channels. It appears that more meadows instead of shrublands in the old fields will represent an increase in the peak-flows, whose consequences in the channels are not yet well known.

It is important to keep in mind that the strong imbalance between summer and winter fodder resources encourages the substitution of cereal crops by meadows in the valley bottoms. But this natural trend of land management conflicts with the policy of reservoir construction, which destroys some of the best cultivated land in the valley. The sustainability of the system largely depends on productive meadows, allowing the maintenance of an acceptable, though very limited, number of sheep and cattle, and avoiding dependence on fodder imported from outside the mountains. In the near future, the only possibility of increasing the livestock numbers is to transform some old fields now covered by dense shrubs ${ }^{\prime}-$ into meadows. From our results it appears that this will not have serious environmental consequences. The construction of new reservoirs will reduce the number of livestock and increase the dependence on tourism. 
Table 1 demonstrates that the cultivated area has become the most important source of food for livestock, representing more than 65 per cent of the total, and almost 80 per cent in the Hecho Valley, where the extensive valley floor is so productive that a surplus is sold to other valleys. The summer pastures are still important, whilst the low and middle slopes are insignificant. Grazing of abandoned fields accounts for between 1 and 5 per cent of the annual food. Finally, the imports from outside became insignificant once transhumance was abandoned but a few valleys, such as the Gállego Valley which is strongly affected by reservoir construction, still purchase fodder to balance the winter deficit (Garcia-Ruiz and Lasanta 1993).

\section{Acknowledgements}

This paper has been produced with financial support from the project 'Erosión del suelo tras el abandono de explotaciones agrícolas en montaña media: interacciones con las estrategias de colonización vegetal, los usos del suelo y la disponibilidad de nutrientes' (AMB 93-0806), funded by the CICYT.

\section{References}

Balcells, E. 1983. Evolución socioeconómica reciente de tres comarcas pirenaicas y destino actual de las superficies más productivas de su demarcación. Cuadernos de Investigación Geográfica 9: 41-82.

Dupré, M. 1990. Historical antecedents of desertification: climatic or anthropological factors? In Strategies to combat desertification in Mediterranean Europe. pp. 2-39. Edited by J.L. Rubio and R.J. Rickson. Commission of the European Communities, Valencia.

Esteva, C. 1971. Para una teoría de la aculturación en el Alto Aragón. Ethrica 2: 9-78.

Garcia-Ruiz,J.M. 1976. Modos de vida y niveles de renta en el Prepirineo del Alto Aragón Occidental. Instituto de Estudios Pirenaicos, Jaca. 272 pp.

Garcia-Ruiz,J.M. 1990.El viejo dilema: estabilidad e inestabilidad de los ecosistemas de montaiia. In Geoecologia de las Areas de montaiia. pp. 317-337. Edited by J.M. Garcia-Ruiz. GeoformaEdiciones, Logroiio.

Garcia-Ruiz, J.M. and Lasanta, T. 1993. Land-use conflicts as a result of land-use changes in the Central Spanish Pyrenees. A review. Mountain Research and Development 13(3): 213-223.

Garcia-Ruiz, J.M. and Ortigosa, L. 1988. Algunos efectos geomorfologicos de las repoblaciones forestales: Cambios en la dinámica de cauces en pequeiias cuencas del Pirineo Central español. Cuaternario y Geomorfologia 2: 33-41.

Garcia-Ruiz, J.M. and Ortigosa, L. 1992. Some geomorphological effects of afforestation techniques in the Central Spanish Pyrenees. Geooko Plus 3: 3744.

Garcia-Ruiz, J.M. and Puigdefábregas, J. 1982. Formas de erosión en el flysch eoceno surpirenaico. Cuadernos de Investigación Geográfica 8: 85-128.

Garcia-Ruiz,J.M., Alvera, B., Del Barrio, G. and Puigdefábregas, J. 1990. Geomorphic processes above timberline in the Spanish Pyrenees. Mountain Research and Development 10(3): 201-214.

Garcia-Ruiz, J.M., Lasanta, T., Ortigosa, L., Ruiz-Flaiio, P., Marti, C. and González, C. 1995. Sediment yield under different land uses in the Spanish Pyrenees. Mountain Research and Development 15(3): 229-240.

Garcia-Ruiz, J.M., Puigdefábregas, J. and Creus, J. 1986. La acumulación de nieve en el Pirineo central y su influencia hidrológica. Pirineos 127: 27-72.

Gómez, D. and Fillat, F. 1984. Utilisation du frene comme arbre fourrager dans les Pyrénées de Huesca. Documents d’Ecologie Pyrénéenne 4: 481489.

Gómez-Villar, A. 1995. Dinámica de conos aluviales en pequeiias cuencas torrenciales de montaiia. Geoforma Ediciones, Logroiio. $200 \mathrm{pp}$.

González, C., Ortigosa, L., Marti, C. and Garcia-Ruiz, J.M. 1995. Use of a Geographical Information System to study the spatial organization of geomorphic processes in mountain areas. Mountain Research and Development 15(3): 241-249.

Gorria, A.J. 1987.Evolución demográfica y crisis de la organización social y económica. El valle de Ansó. Instituto de Estudios Altoaragoneses, Huesca. 216 pp.

Kruger, F. 1939. Die Hochpyrenaen. C. Landliche Arbeit. Band 11. Mansischer Gildeuverlag, Hamburg. 500 pp.

Lasanta, T. 1988. The process of desertion of cultivated areas in the Central Spanish Pyrenees. Pirineos 132: 15-36.

Lasanta, T. 1989a. Evolución reciente de la agricultura de montaiia: el Pirineo aragonés. Geoforma Ediciones, Logroiio. 220 pp.

Lasanta, T. 1989b. Organisation spatiales et dynamique récente de l'utilisation du sol dans les Pyrénees centrales espagnoles. Revue Géographique des Pyrénees et du Sud-Ouest 60(2): 173-198.

Lasanta, T. 1990. Tendances actuelles de l'organisation spatiale des montagnes espagnoles. Annales de Géographie 551: $51-71$.

Lekach, J. and Shick, A.P. 1982. Suspended sediment in desert floods in small catchments. Israel Journal of Earth Sciences 31: 144-156.

López-Bermúdez, F., Garcia-Ruiz, J.M., Romero, M.A., RuizFlaiio, P., Martinez, J. and Lasanta, T. 1993. Medidas de flujos de agua y sedimentos en parcelas experimentales. Geoforma Ediciones, Logroiio. $38 \mathrm{pp}$.

Martinez-Castroviejo, R., Gómez-Villar, A. and Garcia-Ruiz, J.M. 1991. Ajustes fluviales derivados de cambios de usos del suelo en el Pirineo aragonés. Cuaternario y Geomorfologia 5:91-106. 
Molinillo, M., Lasanta, T. and Garcia-Ruiz, J.M. 1994. Sucesión vegetal y recursos pastorales en campos abandonados del Pirineo Central. VII Coloquio de Geografia Rural, Córdoba. pp. 200-207.

Montserrat,J. 1992.Evolución glaciar y postglaciar del clima y la vegetación en la vertiente sur del Pirineo: estudio palinológico. Instituto Pirenaico de Ecologia, Zaragoza. 147 pp.

Ortigosa, L. and Garcia-Ruiz, J.M. 1995. Geomorphological consequences of afforestation at a basin scale. An example from the Central Pyrenees. Physics and Chemistry of the Earth (in press).

Ortigosa, L., Garcia-Ruiz, J.M. and Gil, E. 1990. Land reclamation by reforestation in the Central Pyrenees. Mountain Research and Development 10(3): 281-288.

Poesen, J.W., Torri, D. and Bunte, K. 1994. Effects of rock fragments on soil erosion by water at different spatial scales: a review. Catena 23(1-2): 141-166.

Puigdefábregas, J. and Balcells, E. 1966. Resumen sobre el régimen de explotación ovina trashumante en el Alto Aragbn, especialmente en el valle de Ansb. Publ. Centr. Pir. Biol. Exp. 1(6): 1-18.
Rijckborst, H. 1967. Hydrology of the upper Garonne basin (Valle de Arán, Spain). Leidse Geologische Mededelingen 40: 7-74.

Rubio, V. and Hernández, C. 1990. La evolución reciente del cauce del río Ara. Cuadernos de Investigación Geográfica 16:99-108.

Rubio, V. 1995. Dinámica fluvial del río Ara (Pirineo Argonés). Tesis Universidad Autónoma de Madrid, Madrid. 615 pp.

Ruiz-Flafio, P. 1993. Procesos de erosión en campos abandonados del Pirineo. Geoforma Ediciones, Logrofio. $191 \mathrm{pp}$.

Ruiz-Flaño, P., Garcia-Ruiz, J.M. and Ortigosa, L. 1992. Geomorphological evolution of abandoned fields. A case study in the Central Pyrenees. Catena 19(3-4): 301-308.

Ruiz-Flaiio, P., Lasanta, T., Garcia-Ruiz, J.M. and Ortigosa, L. 1991. The diversity of sediment yield from abandoned fields of the Central Spanish Pyrenees. IAHS Publ. 203: 103-110.

Villar, L. and Garcia-Ruiz, J.M. 1976.Explotación del territorio y evolución de pastos en dos valles del Pirineo Occidental. Publ. Centr. Pir. Biol. Exp. 8: 143-163.

Violant, R. 1949. El Pirineo español. Ed. Plus Ultra, Madrid. $675 \mathrm{pp}$. 